\title{
Sustainable Economic Development Concept and Factors: Global, Regional,Corporate Aspects
}

\author{
Abu Isaevich Avtorhanov \\ doctor of Economics, \\ Professor, \\ head of of economic research laboratoryof CNRI the name \\ of H. I. Ibragimov Russian Academy of Sciences
}

\author{
Maula Abdurahmanovich Betilgiriev \\ doctor of Economics, \\ Professor of Department "Economics and management" \\ GGNTU,
}

GNS of economic research laboratory of CNRI the name of H. I. Ibragimov Russian Academy of Sciences - supervisor. Grozny state oil technical University named after academician M. D. Millionshtchikov

The Institute of Economics and Law.

Comprehensive Research Institute named

after Kh. I. Ibragimov of the Russian Academy of Sciences

Grozny, Russia

betilgiriev@mail.ru

\author{
Raisa Saidmagomedovna Temihanova \\ Graduate student \\ Grozny state oil technical University named academician M. D. Millionshtchikov \\ The Institute of Economics and Law \\ Grozny, Russia
}

\begin{abstract}
The article considers the concept of sustainable development, presents the evolution of the concept of sustainable development, reveals the factors that affect the sustainable development of economic entities. The authors emphasize that sustainable development can be considered in relation to the economy of the country as a whole, the economy of a particular region, the economy of the enterprise. A special role is given to the study of sustainable development of the region. According to the authors, the concept of sustainable development has passed a long evolutionary path and can be divided into three stages: initial, political, stage of socio-economic problems. At the present stage, the concept of "sustainable development" in our country is relevant and the role of the regions in ensuring its sustainable development is constantly increasing. This requires new approaches in the definition of economic regional policy, the development of new forms and methods of sustainable management of socio-economic development of the region. At the same time, the objectives of economic and social development must be defined in terms of its sustainability and environmental imperatives, and extend not only to the macro but also to the micro level.
\end{abstract}

Keywords: sustainability, sustainable economic development, concept, stages of development, regional development, corporate sustainability, sustainable development
Sustainable development is the process of economic and social changes during which natural resources exploration, investments, scientific and technological development direction, personal development and institutional changes correlate with one another and promote existing and future potential in order to meet human demands and ambitions [1].

Sustainable development can be considered in relation to the economy of the country as a whole, the economy of a particular region, the economy of the enterprise. A special role is given to the study of sustainable development of the region. Formation of social, economic and environmental bases for sustainable national development is impossible without participation of local communities finding ways and means to provide sustainable development in regions, cities and villages, thus outlining the necessity for taking into account regional specifics and for defining potential opportunities and existing objective limitations and obstacles.

Sustainable development of regions combined with general pattern of national economic development can be characterized by specific attributes, defined by ratio of leading regional industrial output to the total national output volume, availability of export in a region, provision of resource potential, population mentality, etc. Sustainable development of a region depends primarily on sustainable functioning of its structure-forming industries. Sustainable development of an 
economic entity means its ability to prevent and respond to factors that may cause output reduction. And enterprise is developing sustainably in case it is able to provide the output of necessary range of consumption goods with minimal expenses, efficient usage of production factors and in due time.

Scientific literature currently has about 100 definitions of sustainable development. Commonly this notion is used in the global context describing general development of the mankind. The most widely used definition was provided by the Brundtland Commission report [2]: "Sustainable development is the kind of development that meets the needs of the present without compromising the ability of future generations to meet their own needs". It established two key concepts:

- the concept of "needs", in particular the essential needs of the world's poorest people, to which they should be given overriding priority;

- the idea of limitations which is imposed by the state of technology and social organization on the environment's ability to meet both present and future needs.

For over 40 years the notion of sustainable development has been used in policy documents of different levels: international, national, regional, corporate. Although many sources claim this term appeared in the 1980, it had been implemented into economic theory earlier (in the beginning of the $20^{\text {th }}$ century) by Russian statistician, political activist and economic geography expert Nikolay Oganovsky within the framework of his historical study of agricultural evolution patter and sustainable industrial development [3]. This study provides an original concept of global historical process including industrial, structural, social, demographic, environmental, political and institutional aspects.

The concept of sustainable development has passed a long evolutionary path and can be divided into three stages [4]:

- initial (1968-1972).

- political (1972-1992).

- $\quad$ stage of socio-economic problems (1992-present day) (table 1).

On its first stage the concept of sustainable development was a logical continuation of science environmentalization policy typical for late 1960s-eralty 1970s. The main idea was that acute problems of environment pollution, population growth and natural resources limits pose a threat of imminent global crises in case of following the existing direction for global development: overproduction, overpopulation, environment pollution.

\section{TABLE 1. SUSTAINABLE DEVELOPMENT CONCEPT EVOLUTION}

\begin{tabular}{|c|c|c|}
\hline Stage & Years & Main event expanding the concepts \\
\hline 1 & 2 & 3 \\
\hline \multirow{3}{*}{ 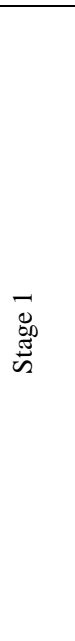 } & 1968 & $\begin{array}{l}\text { Foundation of the Club of Rome - non-governmental } \\
\text { organization created by a group of influential } \\
\text { businessmen, economists, scientists and politicians. The } \\
\text { main aim of the organization is to develop methods for } \\
\text { global crisis analysis in order to achieve the "global } \\
\text { balance". }\end{array}$ \\
\hline & 1970 s & $\begin{array}{l}\text { The formation of sustainable development concept } \\
\text { combining scientific knowledge about the environment } \\
\text { and rapid socio-economic development. Publication of } \\
\text { several scientific works on natural resources limits and } \\
\text { pollution of the environment as the basis of human } \\
\text { activities. }\end{array}$ \\
\hline & 1972 & $\begin{array}{l}\text { The United Nations Conference on the Human } \\
\text { Environment was held in Stockholm resulting in } \\
\text { adoption of United Nations Environment Programme. } \\
\text { This indicated the inclusion of global community in } \\
\text { solving of environmental problems on the state level } \\
\text { resulting in restraint of socio-economic development. }\end{array}$ \\
\hline \multirow[b]{3}{*}{ 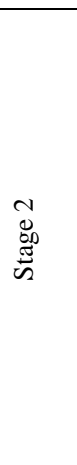 } & 1974 & $\begin{array}{l}\text { Adoption of the second model of the Club of Rome - } \\
\text { Mankind at the Turning Point. }\end{array}$ \\
\hline & 1980 & $\begin{array}{l}\text { Adoption of an international document mentioning the } \\
\text { notion of sustainable development within the framework } \\
\text { of the World Conservation Strategy. }\end{array}$ \\
\hline & 1983 & $\begin{array}{l}\text { The UN Commission chaired by Gro Harlem Brundtland } \\
\text { and established in order to address growing environment, } \\
\text { natural resources and human condition issues } \\
\text { implemented the notion of sustainable development. The } \\
\text { Commission concluded that the current generation must } \\
\text { satisfy their needs without harming the same opportunity } \\
\text { for the following generations. It was decided to establish } \\
\text { sustainable development policy in the interest of all } \\
\text { countries. }\end{array}$ \\
\hline \multirow[b]{2}{*}{ 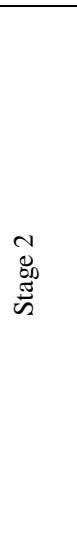 } & 1987 & $\begin{array}{l}\text { The World Commission on Environment and } \\
\text { Development in their Our Common Future report focused } \\
\text { on the necessity for sustainable development "that meets } \\
\text { the needs of the present without compromising the ability } \\
\text { of future generations to meet their own needs". This } \\
\text { definition of sustainable development is widely used as } \\
\text { the basic one in many countries. }\end{array}$ \\
\hline & 1991 & $\begin{array}{l}\text { New IUCN edition titled Caring for the Earth. A Strategy } \\
\text { for Sustainable Living. It pointed out that development } \\
\text { must be based of nature preservation and measures for } \\
\text { protecting biological diversity helping species to develop. } \\
\text { It distinguished three main factors: conservation of life } \\
\text { support systems, conservation of biological diversity and } \\
\text { sustainable usage of renewable energy sources. The } \\
\text { research related to environmental safety as part of } \\
\text { national and global safety began to be conducted. }\end{array}$ \\
\hline
\end{tabular}


TABLE 1. SUSTAINABLE DEVELOPMENT CONCEPT EVOLUTION, CONT

\begin{tabular}{|c|c|c|}
\hline 1 & 2 & 3 \\
\hline \multirow{10}{*}{ 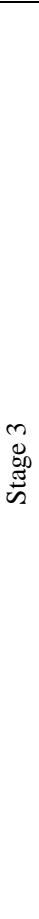 } & 1992 & $\begin{array}{l}\text { The UN Conference on environment and industrial and } \\
\text { consumption changes was held in Rio de Janeiro. One of } \\
\text { its main documents became Agenda } 21 \text { declaring the } \\
\text { necessity for further progress of existing sustainable } \\
\text { development concept. }\end{array}$ \\
\hline & 1993 & UN Conference on Human Rights. \\
\hline & 1994 & UN Conference on Population and Development. \\
\hline & 1995 & $\begin{array}{l}\text { The World Summit for Social Development in } \\
\text { Copenhagen. Adoption of the Berlin Mandate initiating } \\
\text { actions against carbon dioxide emissions. }\end{array}$ \\
\hline & 1997 & $\begin{array}{l}\text { Adoption of the Kyoto Protocol on reducing carbon } \\
\text { dioxide emissions. }\end{array}$ \\
\hline & 2002. & $\begin{array}{l}\text { Adoption of The Johannesburg Plan by the UN Division } \\
\text { for Sustainable Development. This is a ten-year program } \\
\text { based on the sustainable development concept and } \\
\text { promoting involvement of NGOs, business communities } \\
\text { and corporations. }\end{array}$ \\
\hline & $\ldots$ & \\
\hline & \multirow{3}{*}{$\begin{array}{c}\text { Present } \\
\text { day }\end{array}$} & Growing dematerialization of economic activities. \\
\hline & & Emergence of the environmental economy concept. \\
\hline & & $\begin{array}{l}\text { Spreading of the sustainable development concept on the } \\
\text { micro level. }\end{array}$ \\
\hline
\end{tabular}

The second, political stage of sustainable development is related to the spreading of the concept and formation of international institutions. Initially, the global scientific did not realize the practical value of the Club of Rome. This could be explained by the unwillingness of the global community to acknowledge growing issues and the fear of losing the images of "prosperous society" and "post-industrial society" due to the fact that, compared to relatively successful previous decades, this would seem as the revolution collapsing existing worldviews and standards [5].

On its first two stages the concept was aimed at the macro level, clearly demonstrated in 1970 by creation of first global processes simulation models (WORLD1 and WORLD2) designed by Jay Forrester and lately upgraded by Donella and Maedows groups using long-term development (1970-2100) modeling. The development of these models was based on factors stimulating economic and population growth. These factors were divided as physical and social constituents. The first one provided the mechanism efficiency and meant resources provision, while the second impacted employment and social stability levels. The models demonstrated that even in the best-case scenario economic efficiency is steadily declining. To avoid this, the "zero growth" concept was developed, according to which sustainable development means reproduction and strengthening of existing positions [6].

Due to the fact that the first models were criticized for their global approach, the "zero growth" concept was replaced by the "organic growth" concept (coordinated development of separate part of the global system) and the second global model Mankind at the Turning Point was developed by the Club of Rome (1974).

The main idea was not in halting the economic growth but in reducing irresponsible usage of natural resources. The latter is hardly possible in terms of growing competitions and increase of traditional indicators of economic efficiency like profits and labor efficiency. Meanwhile, the transition to "informational society" - the immaterial economy (finances, data, images, messages, intellectual property) leads to dematerialization of economic activities: nowadays the volume of financial deals is 7 times bigger than material goods turnover. The new economy is driven not only by material (and natural) resources deficit, but by the abundance if informational resources and knowledge. Energy intensity of economic activities is steadily reducing while general energy consumption is still growing.

The progress of economic science determined inclusion of the environmental factor. On the one hand, most traditional natural resources became deficit including both non-renewable and renewable energy sources (primarily ecosystem biodiversity resources).

One of the definitions of sustainable development involves "inexhaustible" development in the long-term perspective. The nature acts the basis for human activities; exhaustion and degradation of its resources has a negative effect on social relations, production and consumption structure and causes poverty growth.

On the other hand, most renewable natural resources are valued too low causing their exhaustion and degradation. This calls for the transition to the environmental and sustainable development economy models. Meanwhile, the interaction of social and environmental factors leads to the necessity for inclusion of another factor - the social capital.

The stage of socio-economic problems (Stage 3) is characterized by the dogmatization of the sustainable development concept, accepted by the UN, leading scientists and politicians and by appearance and development of alternative models (e.g. the concepts of regional and corporate sustainability) [7].

On its current stage, the concept of sustainable development has become relevant in Russia and the role of regions in national sustainable development is constantly growing. This requires new approaches to regional economic policy, development of new forms and methods of sustainable regional socio-economic development management [8].

The Johannesburg Plan of 2002 is considered the most upto-date basic document adopted by the UN Division for Sustainable Development. According to Nitin Desai, the General Secretary of the Commission on Sustainable Development, the Johannesburg Plan is a more targeted document than Agenda 21 [9]. In fact, this is a ten-year program of actions based on participation of partnerships, NGOs, business communities and corporations. 
This may be one of the reasons why the notion of sustainable development is more commonly used within the corporate culture of large companies and reflects their activities aimed at reducing negative social and economic consequences of achieving growth or at least economic balance and system sustainability. The sustainability characterized by the balance of the system means the ability of the system to return to its initial state, when the impact of a factor causing a system imbalance is no longer present. This balance providing stable income and potential for economic growth in the long-term perspective can be achieved only by taking into account external and internal factors of sustainable development of a company. This approach is represented in Tektology: Universal Organization Science, a famous work by A. Bogdanov, who was one of the first researchers applying the notion of sustainability to organizations. According to A. Bogdanov, sustainability can be viewed in relation to the structure of the system or functions determining its functioning. Bogdanov describes sustainability of the first type characterized by the ability of the system to return to its initial state after balance disruption and sustainability of the second type during which the system after losing its balance reaches a new stage of development. Unstable systems are defined by the author as systems incapable of acquiring a new stage or returning to the previous one; they collapse after the impact of negative factors [10].

Modern transition to the corporate stability model is determined mostly not by willingness of corporations to satisfy social needs but by the basic necessity for their survival. According to J. Elkington, the transition of global economy to a new corporate sustainability paradigm is determined by changes in requirements set by the environment [11]. The interaction of internal and external factors changes the possibilities of a company and social policy and sets new objectives enabling sustainable development. Modern scientific literature pays much attention to factors of sustainable development of a company; however, general opinion on this direction has not been formulated yet and only two common aspects can be distinguished:

\section{Division between internal and external factors.}

\section{Division between and indirect factors.}

There is a controversial point of view that external factors are independent from companies' activity [12]. We believe this claim not to be true in all cases, because alongside global challenges that are hard to forecast (like inflation, political and economic instabilities, market imbalance), there exists a set of strategic, technological and social factors depending on the organization. The external factors are aggressively and indirectly influencing company processes and limiting its activity. Organizations cannot ignore external factors that include a large number of key stakeholders (consumers, local communities and state bodies). External factors are basically the main challenge and the principal matter of survival for an organization. It is the necessity for survival that forces companies to quickly respond to external changes reducing their negative impact.

External factors may be relatively divided as direct and indirect ones.
Direct factors have a direct influence on sustainable development of the company and are influenced directly by its activities. These factors include interaction with key stakeholders of the organization: suppliers of economic resources (financial, labor, informational, material and others), consumers, media, state bodies, competitors and others.

Indirect factors have indirect impact on sustainable development. They include current economic situation, relevant social and political issues, regulation of activities, current legislation and demographic situation.

Internal factors act within the organization influencing its external functioning and general development, because internal environment of the company is the total amount of its internal elements, systems, subsystems and processes influencing its development ability, potential and competitiveness. It is characterized by strategic objectives, task-setting, structure, technologies, personnel and many other constituents. Internal environment of the organization is a part of its general environment and is constantly and directly influencing its activity. Due to external environment heterogeneity and its multiple constituents including key processes end elements of the organization, internal factors of sustainable development of the company are considered to be dependent ones. That means enterprises may adjust and influence them.

Factors of internal sustainable development of the organization include the following:

- financial potential (financial indicators and investment possibilities);

- personnel potential (human and social capital;

- business potential (goodwill and reputational capital);

- market potential (demand for the product, company market share);

- labor potential (industrial factors organization and market including labor market);

- industrial potential (production volume);

- research and development potential (opportunity for $\mathrm{R} \& \mathrm{D}$ activities).

The origin of the factors also plays an important role, because:

- the company may directly interact with internal factors,

- the company may interact with direct external factors,

- indirect external factors are beyond the company's influence.

The company activities must not cause, even indirectly, a decrease of quality of life and well-being of any of its stakeholders. Working conditions and consumers' satisfaction, absence of negative influence of the company's production activities on the external environment and local residents, stakeholders' loyalty to the brand are the reasons and causes for sustainable development of the company. 
These company sustainable development factors determine the main criteria for its existence - competitiveness, strategic advantages and, consequently, profitability, long-term development perspectives and sustainability. Obviously, corporate sustainability should not be viewed only as the theory of providing company survival in the long-term perspective (although it is its integral part) but also as the field for theory and practice within environmental, social and economic aspects. This would promote competitive advantages and corporate survival principles.

Survival is the focus of the concept of corporate sustainability. Average lifespan of a company is a relatively short period and solving the task of company survival depends on external factors. For instance, oil crisis of the 1970 resulted in the agony of prosperous US automobile industry. This caused the bankruptcy of many national manufacturers. Many Russian companies that demonstrated their inability to work in crisis conditions had to leave the market as well.

Average lifespan of companies is relatively short - out of thirty companies included in Financial Times Ordinary ShareIndex in 1935, only nine continued their existence in the late 1990s. Among US corporations, over $40 \%$ of companies included in Fortune-500 in 1983 and 60\% of companies included in Fortune-500 in the 1970 left the market by the late 1990s; and of 12 companies comprising Dow Jones Industrial index in 1900, only General Electric continued its existence. Although average lifespan of a corporation may reach 40-50 years, there are hundreds of companies existing for 100-10 years or more. Such cases of sustainability can be explained by correspondence of strategic actions to corporate sustainability factors, which fulfillment promotes increase of shareholder value and competitive advantages, thus favoring profitability. Eventually, it is profitability that determines company possibilities and the reason for its existence.

Thus, corporate stability acts as a new sustainable development paradigm aimed at company survival priorities based on never-ending struggle for competitive positions and profitability by using internal and external factors and reducing potential threats.

In modern economic conditions activity of any organization influenced by objective and multidirectional macro and microeconomic factors may be susceptible to permanent risk of losing its sustainability and development trajectory [13].

Preparedness of the organization to these impacts affects its ability to respond to them. Sustainability of any organization is also influenced by various factors: production, sales, strategic and personnel managements, etc.

In fact, sustainability and changeability may be analyzed as to mutually completing and dependent characteristics of the organization. For instance, constant improvement (sustainability) policy may promote implementation of new working methods (changeability). Similarly, new products (changeability) may induce increase of survival possibility (sustainability). Furthermore, it may be concluded that ability to finance expenses related to organizational changes eventually depends on rate of return as of stability characteristics.

It must be noted that organizations continue their existence only in case they are able to maintain the balance between changeability and sustainability. There is no "miraculous" way for estimating the exact balance between sustainability and changeability levels and most probably, these indicators will vary for companies acting in different contexts, in particular in competitive and rapidly changing environment.

Thus, tasks for economic and social development must be set taking into account its sustainability and correspondence to environmental imperative in all countries (developed and developing countries, countries with market or other types of economy) and applied on both macro- and micro-levels. This determines the importance of formation and further development of the concept of sustainable development.

\section{References}

https://ru.wikipedia.org/wiki/\%D0\%A3\%D1\%81\%D1\%82\%D0\%BE\% D0\%B9\%D1\%87\%D0\%B8\%D0\%B2\%D0\%BE\%D0\%B5 \%D1\%80\% D0\%B0\%D0\%B7\%D0\%B2\%D0\%B8\%D1\%82\%D0\%B8\%D0\%B5

[2] Brundtland G.H. Nashe obsheye budusheye. Doklad Komissii OON po okruzhayushey srede i razvitiyu (1987 g.) [Our Common Future. The World Commission on Environment and Development Report (1987)]. Moscow: Progress, 1988.

[3] Agrarno-evotyutsionnaya teoriya narodnichestva. [Argicutural evolutinal theory of the Narodniks]. - Available at: http://inecon.org/docs/Oganovsky.pdf

[4] Belousov K.Y. Sovremenny etap evotyutsii kontseptsii stabilnogo razvitiya $\mathrm{i}$ formirovaniye paradigmy korportaivnoy ustoychivosti [Contemporary stage of evolution of the sustainable development concept and formation of the corporate sustainability paradigm] // Problemy sovremennoy ekonomiki [Problems of modern economy]. 2013, N.1 (45). - Available at: http://www.meconomy.ru/art.php?nArtId=4424.

[5] Chumakov A.N. Globalizatsiya. Kontury tselostnogo mira: monografiya [Globalization. Contours of the whole world: monography]. - Moscow: Prospekt, 2009.

[6] Predely rosta [The Limits to Growth] / D. Meadows, J. Raders, D. Meadows, W. Behrens. - Moscow: Moscow State University Publishing House, 1999.

[7] Blagov Y.E. Korporativnaya sotsialnaya otvetsvennost: evolutsiya kontseptsii [Corporate social responsibility: concept evolution]. - Saint Petersburg: Saint Petersburg State University, 2010.

[8] Hairullov D.S., Yeremeev L.M. Problemy ustoychivosti sotsialnoekonomicheskogo razvitiya regiona [Problems of sustainability of socioeconomic developmet of a region]. // Vestnik Kazanskogo gosudarstvennogo argarnogo universiteta. [Proceedings of Kazan State Agricultural University]. Kazan, 2012, N.1. PP. 73-76.

[9] 2002 Johannesburg Summit - the World Summit on Sustainable Development official website. - Assessment of Johannesburg Summit results. $\quad$ - Available http://www.un.org/russian/conferen/wssd/story.htm

[10] Bogdanov A.A. Tektologiya. Vsheobshaya organizatsionnaya nauka, kn. 1-2. [Tektology. Universal Organization Science. Vol. 1-2]. - Moscow, 1989 .

[11] Elkington, J. 1994. Towards the Sustainable Corporation: Win-Win-Win Business Strategies for Sustainable Development. California Management Review 36(2).

[12] T. Strange and A. Bayley, «Sustainable Development» Organization for Economic Co-operation and Development (OECD) Press, Paris, 2008. 